\title{
O Carnaval de Manuel Bandeira e a commedia dell'arte
}

Graziela Chequer ${ }^{1}$

Resumo: Manuel Bandeira publicou Carnaval (1919) em um contexto artístico específico, quando músicos, pintores e escritores do final do século XIX e primeiros anos do século XX (simbolistas e primeiros modernistas) se inspiraram na commedia dell'arte, teatro de origem popular baseado nas máscaras, na mímica e no improviso. A relação mais estreita dos poetas com a commedia se deu através de um Pierrot de caráter lunar, que descende das pinturas de A. Watteau e da personagem recriada no teatro de funâmbulos por J-G. Deburau. Identificado com o que há de triste e solitário na vida e no trabalho do poeta, é a figura arquetípica de Pierrot que estrutura grande parte de Carnaval, contribuindo para o predomínio de uma atmosfera neo-simbolista, onde a melancolia e o "mau destino" aparecem tratados não em um tom solene e diretamente confessional, mas mediados pela commedia dell'arte.

Palavras-chave: Poesia brasileira. Manuel Bandeira. Carnaval. Commedia dell'arte.

\section{O contexto: a commedia dell'arte e as vanguardas europeias}

Manuel Bandeira publicou o seu segundo livro, Carnaval, em 1919, momento particularmente rico em obras de arte de vanguarda que retomaram elementos da cultura carnavalesca e da commedia dell'arte.

A commedia serve de inspiração para Carnaval (1994) e o poeta se vale de seus motivos e de suas personagens para criar uma espécie de eixo em torno do qual comunica uma emoção poética variada, instável. Com isso, o livro ocupa um lugar específico no conjunto da obra do poeta, sendo talvez aquele que mais diferenças e peculiaridades tenha em relação ao todo.

Dos trinta e três poemas que compõem Carnaval, onze trazem expressamente, no título ou no corpo, personagens da commedia dell'arte: "A canção das lágrimas de Pierrot", "A rosa", "Pierrot branco", "A silhueta", "Arlequinada", "Pierrot místico", "Pierrette", "Rondó de Colombina", "O descante de Arlequim", "Sonho de uma terça-feira gorda" e "Poema de uma quarta-feira de cinzas".

A commedia dell'arte compartilha muitos elementos com o circo, o carnaval, a pantomima, os bufões medievais e renascentistas, o teatro de marionetes e de funâmbulos, os

\footnotetext{
${ }^{1}$ Mestre em Estudos Literários pela Faculdade de Letras da Universidade Federal de Minas Gerais. E-mail: grazichequerr@hotmail.com.
} 
acrobatas e os espetáculos de variedades. Ela tem um caráter "não-oficial" ou "antioficial" por excelência. ${ }^{2}$ Calcada no improviso, na estilização ("sinceridade" e representação não são valores que se aplicam aqui), a commedia tem a ver com artifício, com nonsense. É um mundo que "possui uma integridade e leis estéticas especiais, um critério próprio de perfeição não subordinado à estética clássica da beleza e do sublime" (BAKHTIN, 1987, p. 31). No teatro de commedia - diferente do teatro convencional, que tem por base um texto literário - a realidade objetiva quase não tem importância.

A celebração do carnaval precede a commedia, que de certo modo descende dele. $\mathrm{O}$ estudo de Bakhtin continua sendo fundamental para a compreensão do que ele chamou de "cultura carnavalesca", parte importante da cultura cômica popular medieval, e que deve ser vista como "una e indivisível”, mesmo com suas múltiplas manifestações: festejos carnavalescos, festa do asno, festa dos loucos, dos tolos, gigantes, anões e monstros que se exibiam nas feiras, palhaços de diversos estilos e categorias (Cf. BAKHTIN, 1987, p. 3-4).

Carnaval e commedia têm em comum a ousadia da invenção (em oposição à mimesis), a associação de elementos heterogêneos, a libertação de todas as convenções, ajudando a compor um olhar que seja capaz de perceber "até que ponto é relativo tudo o que existe" (BAKHTIN, 1987, p. 30).

Baseada no riso e na sátira dos cidadãos e dos costumes locais, sempre com algo de frívolo e grotesco, a commedia dell'arte renascentista fez um sonoro contraponto ao temperamento sério burguês que, contemporâneo dela, prevaleceria nos séculos seguintes. Mas aqui é preciso ponderar que, embora oposta aos valores dominantes, a commedia nunca foi ideológica, o que a distingue de outras formas de radicalismo político ou artístico (Cf. GREEN; SWAN, 1986, p. xiii-xiv). O seu caráter sempre foi o de entretenimento, pelo menos até que compositores, pintores, romancistas e poetas do final do século XIX e primeiros anos do século XX (simbolistas e primeiros modernistas) se sentissem atraídos por ela, e incorporassem seu espírito e seus motivos em obras de arte (Cf. GREEN; SWAN, 1986, p. 1).

Num longo arco que se estende das pinturas de Antoine Watteau (1684-1721) e do Pierrot recriado pelo ator Jean-Gaspard Deburau (1796-1846) às vanguardas europeias do

\footnotetext{
${ }^{2}$ Cf. GREEN e SWAN. The triumph of Pierrot: the commedia dell'arte and the modern imagination. Esta obra trata do retorno da commedia dell'arte nas obras de vanguarda modernista europeia e Russa, sobretudo no período compreendido entre 1890 e 1930. A ideia central é a de que há um parentesco mais ou menos explícito de um grande número de obras modernas com a commedia. Originalmente italiana, renascentista, popular e transgressora, os autores analisam a apropriação que dela fizeram os artistas cultos franceses nos séculos seguintes.
} 
início do século XX, a commedia passou a inspirar artistas cultos - deixou o mundo popular, as esquinas, as feiras, o teatro de Funâmbulos, e chegou ao mundo da arte moderna.

As séries de Watteau retratando Gilles (Pierrot) tornaram-se conhecidas e foram muito importantes na formação de uma aliança entre a commedia italiana popular e a cultura francesa "elevada". Revalorizadas por Baudelaire, essas pinturas interessaram a outros pintores e poetas franceses. Mais do que isso, constituíram, elas mesmas, a imagem da nova commedia, agora impregnada do gosto culto francês.

Outro artista que teve um papel central na criação de um laço entre a commedia, o teatro culto e a poesia na França foi Jean-Gaspard Deburau. No teatro de Funâmbulos, Deburau recriou Pierrot, e foi esse Pierrot que encantou os poetas simbolistas franceses, com sua túnica simples, negra, sem gola - toda a ênfase posta nos aspectos emocionais. É através do trabalho de Deburau que a commedia incorpora a melancolia e o senso estético com os quais passará à literatura.

Depois de Deburau e Baudelaire, outros artistas, em suas obras, questionaram pela primeira vez o estilo solene - sobretudo Jules Laforgue (1860-1887) e, no século XX, Igor Fyodorovich Stravinski, Serge Diaghilev e Pablo Picasso.

A despeito desse ambiente artístico que existia no momento da publicação de Carnaval, é possível aceitar que o tema tenha sido apenas um "pretexto" para a publicação de uma coletânea heterogênea de poemas, se dermos inteiro crédito às palavras de Manuel Bandeira: "É um livro sem unidade. Sob o pretexto de que no carnaval todas as fantasias se permitem, admiti na coletânea uns fundos de gaveta [...]" (BANDEIRA, 1984, p. 60).

Entretanto, numa obra concisa, em que acasos e arranjos desse tipo não existem, criada por um poeta que foi também crítico de $\operatorname{arte}^{3}$ e precursor da poesia modernista no Brasil movimento que tornou mais estreito o diálogo entre as diferentes artes - melhor seria compreendermos o Carnaval ao lado de outras obras modernistas inspiradas na commedia, que vieram um pouco antes ou um pouco depois dele: o balé Petrushka estreou em 1911, em Paris; o Pierrot Lunaire, de Arnold Schoenberg, em 1912, em Berlim; a série de Pierrot e palhaços trágicos expressionistas de Georges Rouault teve início em 1907 e se estendeu por quase toda a obra do pintor; os Arlequins de Picasso vão de 1901 até os anos 30, transcendendo os limites das "fases" de sua obra.

\footnotetext{
${ }^{3}$ Manuel Bandeira exerceu regularmente, em suas crônicas, uma crítica de arte abrangente, sobretudo em relação às artes plásticas e à música, mas contemplando também o teatro, a dança e o cinema. Essa crítica pode ser lida principalmente em Andorinha, Andorinha (nas edições com organização de Carlos Drummond de Andrade há uma divisão em seções dedicadas a cada arte), Crônicas da província do Brasil, Crítica de arte, Crônicas inéditas I e Crônicas inéditas 2.
} 
A relação entre a commedia e a arte modernista deve muito à Companhia dos Balés Russos. Sob a direção de Serge Diaghilev (1872-1929), o balé russo deixou a respeitabilidade dos teatros de São Petersburgo e se aproximou do universo do circo e do carnaval. Em 1911, houve a estreia mundial de Petrushka, em Paris. Em 1920, Diaghilev retornou explicitamente à commedia e trabalhou de novo com Stravinski no balé Pulcinella .

A companhia dos Balés Russos trazia, de um lado, a beleza e a riqueza de uma arte onde havia o gosto pela estilização e pela fantasia. Por outra via, muitas vezes pelo exagero da sensualidade, pelo grotesco, pela falta de linearidade, suas montagens questionavam as convenções sociais e estéticas, expondo uma contradição entre arte e valores morais e sociais, entre arte e realidade, em última instância entre arte e verdade, questionamento que está na base da sensibilidade moderna que o balé de vanguarda dos russos ajudou a formar.

Como se vê, a assimilação da commedia pelos modernistas europeus aconteceu principalmente através da dança (Balés Russos), da música (sobretudo de Stravinski e Schoenberg) e da pintura (sobretudo de Picasso e Rouault). Na literatura, as obras com esse tipo de inspiração talvez não tenham sido tão numerosas, ou talvez não tenham alcançado tanta repercussão. Nesse sentido, Bandeira ocupa, com o seu Carnaval, um lugar importante, comparável ao de Laforgue.

Liberdade, improviso, estilização, paródia, ironia, fragmentação (de si mesmo, da arte), nonsense como contraponto à representação, tudo isso se interpenetra na commedia dell'arte, e tudo isso foi importante na criação de uma sensibilidade moderna. Surge, assim, uma zona de espelhamento entre a arte popular e a arte culta, que teve início com os românticos e os simbolistas, estes os primeiros a "oficializarem" a commedia.

Esse processo não se deu de modo simples ou sem contradições. Nos anos 10 e 20 do século passado, período em que se situam as obras modernistas citadas, inclusive o Carnaval, de Bandeira, a incorporação da commedia se deu num contexto amplo de oposição às "velhas ideias" de arte e de sociedade, e por "velhas ideias" se entendiam muito do humanismo, da tradição do belo e do sublime, e do próprio simbolismo (Cf. GREEN; SWAN, 1986, p. 257; e STAROBINSKI, 2007, p. 11). É na esteira dessa espécie de protesto que vem o verso de abertura de Carnaval: "Quero beber! cantar asneiras". Entretanto, ao longo do livro, sobre essa intenção inicial, anunciada em alto e bom som, paira a figura espectral de um Pierrot melancólico, que deve quase tudo à tradição simbolista.

A despeito de sua inserção no contexto das obras de vanguarda dos primeiros anos do século XX, não se quer, com isso, colocar o Carnaval como um livro francamente 
modernista. Aqui, nos interessa mais uma definição de poesia moderna em que a dicotomia entre simbolismo e modernismo conte menos, em que seja possível considerar como moderna toda a poesia que vem "depois de Whitman e Baudelaire, Rimbaud e Mallarmé" (ENZENSBERGER, 1985, p. 33).

Carnaval é um livro de transição e, ao lado de traços líricos neo-simbolistas (que prevalecem na recriação de sua figura central, Pierrot), observa-se uma perspectiva irônica e provocativa, já prenunciando o primeiro momento do movimento modernista que aconteceria poucos anos depois.

\section{Literatura e commedia: a figura central de Pierrot}

Ao final do século [XIX], o teatro popular estará definitivamente morto, mas a personagem de Pierrot, como a de Arlequim, terá passado à mão dos escritores "cultos": terá se convertido em um tema literário, impregnado frequentemente de uma ironia fúnebre, um lugar comum em poesia e um disfarce de baile de máscaras. Imagens residuais (STAROBINSKI, 2007, p. 19).

A relação mais estreita dos poetas com a commedia e com o carnaval se dá através da figura de Pierrot, e acontece primeiro na França, a partir da influência da personagem tal como recriada por Deburau. Para a literatura - não é exagerado dizer - Pierrot nasceu simbolista, impregnado de melancolia, embora nele caibam também graça aérea, elegância e até o crime, numa instabilidade ou alternância de humour que é própria do artifício, da commedia (GREEN; SWAN, 1986, p. 18). A triste sina de Pierrot encontra abrigo e novo alento na atmosfera romântica, simbolista e decadentista, com seu "gosto de buscar a própria dor", como se vê no "Rondó de Colombina":

O seu desencanto não tem um fim.

Pobre Pierrot! Não lhe queiras assim.

Que são teus amores?...- ingenuidade

E o gosto de buscar a própria dor.

Ela é de dois?...Pois aceita a metade!

Que essa metade é talvez todo o amor

De Colombina...

(BANDEIRA, 1994).

Pierrot é a figura central do Carnaval de Manuel Bandeira. Aparece no título de quatro poemas e no corpo de mais outros quatro. A personagem tem uma tradição literária que lhe é 
própria, instalada principalmente pela obra de Jules Laforgue, mas também de Gustave Flaubert, Charles Baudelaire, Paul Verlaine, Arthur Rimbaud e Stéphane Mallarmé. No século seguinte, T. S. Eliot (admirador de Laforgue), Edith Sitwell, Guillaume Apollinaire e o próprio Bandeira o retomam como tema.

$\mathrm{Na}$ obra de Laforgue, Pierrot assume a primeira pessoa em vários poemas, sobretudo em seu segundo livro, L'imitation de Notre-Dame la Lune. Aqui, entretanto, o tom será mais coloquial do que no Carnaval de Bandeira, acompanhado de uma ironia cortante, que por vezes provoca o "riso amargo" (Cf. REZENDE, 1997, p. 18). A primeira estrofe de "Outro lamento de lord Pierrô", na tradução de Augusto de Campos, dá uma ideia da locução particular de Laforgue, e mostra como o seu Pierrot se distancia daquele de Bandeira:

Essa que vai me pôr ao corrente da Fêmea!

Eu lhe direi, então, com ares indiscretos:

"A soma dos ângulos de um triângulo, minh'alma,

"É igual a dois retos".

As razões da apropriação da figura do palhaço trágico (Cf. STAROBINSKI, 2007, p. 67$69)^{5}$, pelos artistas dos séculos XIX e XX, do qual Pierrot é uma representação, foram estudadas pelo crítico Jean Starobinski, que fez uma investigação delicada desse processo. $\mathrm{Na}$ visão de Starobinski, esses artistas viram a si mesmos e à sua arte na tristeza de Pierrot e do palhaço trágico, numa "forma particular de identificação":

[...] a escolha da imagem do palhaço não é apenas a escolha de um motivo pictórico ou poético, e sim uma forma indireta e paródica de conceber a questão da arte. Desde o romantismo (ainda que existam alguns precedentes), o cômico, o saltimbanco e o palhaço têm sido imagens hiperbólicas e a propósito deformantes, com as quais os artistas quiseram mostrar a si mesmos e expor a própria natureza da arte. Se trata de um autorretrato encoberto, cuja intenção não se limita à caricatura sarcástica ou dolorosa (STAROBINSKI, 2007, p. 8).

Em Baudelaire esse autorretrato se revela e se aprofunda nos Pequenos poemas em prosa (edição póstuma, 1868). É nessa obra que Baudelaire melhor fixa "o arquétipo do palhaço trágico, cuja imagem se perpetuará através da literatura e da pintura por vários decênios" (STAROBINSKI, 2007, p. 68). O Pierrot de caráter lunar de Laforgue, de Bandeira,

\footnotetext{
${ }^{4}$ Cf. http://www.germinaliteratura.com.br/2008/officina23.htm.

5 A expressão "palhaço trágico" é usada por Jean Starobinski, e não guarda relação com a tragédia como gênero, e sim com o destino infeliz do palhaço, do saltimbanco, do artista. 
os palhaços trágicos expressionistas de Roualt, em todos eles há algo da visão de Baudelaire, do paralelo doloroso que o poeta construiu entre o cômico-bufão-saltimbanco e o artista.

"O Velho Saltimbanco" se inicia com uma descrição viva e muito crítica de uma feira parisiense, habitat da cultura carnavalesca. Quando aparece o saltimbanco, ele não é só penúria e miséria física. Mais do que isso, está inerte, em um embotamento completo do espírito:

No extremo, no último extremo do renque de barracas, como se, corrido de vergonha, se houvesse exilado de todos aqueles esplendores, vi um pobre saltimbanco, arqueado, caduco, decrépito, uma ruína humana, encostado a uma das estacas de sua choça, uma choça mais miserável que a do selvagem mais embrutecido [...].

[...] Aqui, a miséria absoluta, a miséria dissimulada, para cúmulo de horror, sob traços cômicos, em que a necessidade, bem mais do que a arte, introduzira o contraste. Ele não ria, o miserável! Não chorava, não dançava, não gesticulava, não gritava; não cantava nenhuma canção, nem alegre nem lamentosa, não implorava. Mudo e imóvel. Renunciara, abdicara. Estava cumprido o seu destino (BAUDELAIRE, 1976, p. 44-45).

Por fim, o narrador confunde-se com o poeta quando estabelece o paralelo imediato, revelador:

E, voltando-me, perseguido por aquela visão, busquei analisar a minha repentina dor, e disse de mim para mim: - "Acabo de ver a imagem do velho homem de letras que sobreviveu à geração a quem divertiu brilhantemente; do velho poeta sem amigos, sem família, sem filhos, degradado pela própria miséria e pela ingratidão pública, e em cuja barraca o mundo esquecidiço já não quer entrar!” (BAUDELAIRE, 1976, p. 44-45).

Em "Morte Heroica", a identificação do artista cômico com o poeta é mais indireta, e se dá através do triste destino do bufão Fanciullo, surpreendido pela morte em cena, no auge de sua interpretação. O bufão e o saltimbanco, como o poeta, estão fadados ao esquecimento, ao fim trágico, solitário.

Por que Baudelaire elegeu a figura do cômico e do saltimbanco para representar-se e representar a própria arte? Talvez porque eles ocupem uma posição intermediária, menosprezada, artistas para uns e não para outros, trabalhando com o riso - confundido com o que é frívolo, dispensável - em uma sociedade que rapidamente progredia amparada pela técnica e pela ciência, mundo novo que o poeta criticou com uma lucidez impressionante; talvez porque tenha sentido o que há de sombrio no riso de um artista errante, sem palco fixo, como um poeta que não encontra guarida nos velhos ideais de beleza. 
Há uma aproximação evidente entre o velho saltimbanco, Fanciullo, o bobo que suplica em vão ("O Bobo e a Vênus") e Pierrot, todos eles compondo variantes da figura do palhaço trágico com a qual Baudelaire e outros poetas se identificaram.

É nessa esteira que vem o Pierrot de Manuel Bandeira. Ele tem afinidades com o Gilles de face lunar de Watteau, com o Pierrot melancólico de Deburau, com os bufões de Baudelaire, com o que há de triste e solitário na vida e no trabalho do poeta.

Mas é importante dizer que a construção que Bandeira faz de Pierrot transcende o campo da identificação pessoal, da coincidência biográfica em relação à melancolia, ao amor irrealizado e à solidão do poeta. O seu "interesse particular" no mito do palhaço trágico passa também por outros elementos, que surgem imbricados em muitos poemas de Carnaval. Bandeira captou como poucos, e não apenas por sua história de vida, mas sobretudo como artista, a "figura sincrética" de Pierrot (STAROBINSKI, 2007, p. 62), que estrutura grande parte do livro.

\section{Pierrot acrobata: entre as alturas e o abismo}

Pierrot faz a sua primeira aparição no Carnaval em "A canção das lágrimas de Pierrot", terceiro poema do livro, logo após "Bacanal" e "Os Sapos". Trata-se de uma introdução ao ambiente da commedia através de sua personagem mais significativa para os poetas.

"A canção das lágrimas de Pierrot" é o poema mais longo do livro, e isso é significativo, já que na obra de Bandeira os poemas curtos sempre predominaram. A que vem tão longa introdução ao tema?

A sala em espelhos brilha

Com lustros de dez mil velas.

Miríades de rodelas

Multicores - maravilha! -

$5 \quad$ Torvelinham no ar que alaga

O cloretilo e se toma

Daquele mesclado aroma

De carnes e de bisnaga.

E rodam mais que confete,

10 Em farândolas quebradas,

Cabeças desassisadas, 
$\mathrm{S} \quad \mathrm{T} \quad \mathrm{A}$

N. 25 - 2013.1 - GRAZIELA CHEQUER

Por Colombina ou Pierrette.

II

Pierrot entra em salto súbito.

Upa! Que força o levanta?

E enquanto a turba se espanta,

Ei-lo se roja em decúbito.

5 A tez, antes melancólica,

Brilha. A cara careteia.

Canta. Toca. E com tal veia,

Com tanta paixão diabólica,

Tanta, que se lhe ensanguentam

10 Os dedos. Fibra por fibra,

Toda a sua essência vibra

Nas cordas que se arrebentam.

III

Seu alaúde de plátano

Milagre é que não se quebre.

$\mathrm{E}$ a sua fronte arde em febre,

Ai dele! e os cuidados matam-no.

5 Ai dele! que essa alegria,

Aquelas canções, aquele

Surto não é mais, ai dele!

Do que uma imensa ironia.

Fazendo à cantiga louca

10 Dolorido contracanto,

Por dentro borbulha o pranto

Como outra voz de outra boca:

\section{IV}

- "Negaste a pele macia

"À minha linda paixão!

"E irás entregá-la um dia

"Aos feios vermes do chão...

$5 \quad$ "Fiz por ver se te podia

“Amolecer - e não pude!

"Em vão pela noite fria

"Devasto o meu alaúde...

"Minha paz, minha alegria,

10 "Minha coragem, roubaste-mas...

"E hoje a minh'alma sombria

"É como um poço de lástimas..." 


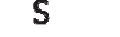

Corre após a amada esquiva.

Procura o precário ensejo

De matar o seu desejo

Numa carícia furtiva.

5 E encontrando-o Colombina,

Se lhe dá, lesta, à socapa,

Em vez de beijo uma tapa,

O pobre rosto ilumina-se-lhe!...

Ele que estava de rastros,

10 Pula, e tão alto se eleva,

Como se fosse na treva

Romper a esfera dos astros!...

(BANDEIRA, 1994).

Com uma organização formal bem definida, o poema vem dividido em partes numeradas de I a V (recurso muito raro na obra de Bandeira), cada uma delas composta por três quadras de versos heptassílabos, próprios da canção popular, como é essencialmente popular a commedia. As rimas acontecem segundo o esquema abba, cddc, etc. A divisão em partes parece essencial à intenção poética e ajuda a criar cenas diferentes, ainda que interrelacionadas.

$\mathrm{Na}$ primeira parte o poeta apresenta de modo pictórico o ambiente de um salão carnavalesco: o brilho das luzes, reforçado pelos sinônimos, dez mil velas / miríades e ainda pela aliteração, mil / miríades / multicores / maravilha; o cloretilo, droga alucinógena; a dança (quebrada, sugerindo desordem e descontrole da turba) e, por fim, o erotismo, no aroma de carnes e no desejo por Colombina ou Pierrete. São três quadras nas quais a evocação dos sentidos aparece concentrada e é crescente: a visão das luzes, o cheiro duplamente inebriante (do lança-perfume e de carnes) e por fim o desejo sexual assumido, especificado.

Erotismo e movimento estruturam essa primeira parte. O movimento é intenso e de ordem circular, onde tudo gira: as luzes, o ar que se dissipa, as cabeças. Essa vertigem que se instalou a partir dos sentidos (aguçados ou liberados pelo cloretilo), produz mais movimento e mais vertigem, num ciclo que é perfeitamente captado pela imagem do torvelinho.

O primeiro verso da parte II instala um corte - sadio, podemos dizer - naquela atmosfera inebriante: "Pierrot entra em salto súbito" é uma alusão à leveza e ao vigor de uma personagem nova, que não estava no salão quando este era só torpor e sensualidade.

Já foi mencionada a "graça aérea" de Pierrot. Ela descende do encanto que os acrobatas e bailarinas dos espetáculos de variedades e dos desfiles carnavalescos exerceram 
sobre os artistas da commedia. Arlequim fazia muitas de suas trapaças valendo-se de acrobacias; muitos bufões e palhaços eram também acrobatas. O salto aparece no Pierrot francês de Deburau, que acentuou as habilidades de acrobata da personagem, impressionando escritores como Gautier:

Deburau teve a sorte de cursar seus estudos clássicos sobre o tablado nas praças e esquinas. Caminhava de cabeça para baixo, transportava escadas na ponta do nariz, tamborilava a nuca com os calcanhares [...], fazia o salto mortal, era o que, em termos artísticos, se chama um homem elástico, que se quebra e se desloca (STAROBINSKI, 2007, p. 23).

Em Les enfants du paradis (filme dirigido por Marcel Carné, em 1945), Jean-Louis Barrault interpretou Deburau, dando ênfase à mímica e aos movimentos, que são cheios de graça e leveza todo o tempo - um ator bailarino-acrobata. Sem um roteiro a ser decorado, as acrobacias e a mímica, também improvisadas, eram recebidas com grande admiração e ajudavam a compor o caráter cômico do teatro de commedia, exigindo do ator múltiplos talentos e habilidades corporais.

Quando os pintores e poetas revalorizaram o circo, muitas questões estiveram envolvidas. A primeira delas, talvez a mais imediata, é a questão romântica do retorno ao que é popular e primitivo; imagens do circo como um contraponto aos grandes temas e imagens que interessaram, até então, à arte ocidental.

Em uma outra vertente já mencionada, pode-se pensar o circo, o carnaval e a commedia como espaços de liberdade, dotados de uma vida própria, uma outra vida, que não a da realidade imediata com suas hierarquias e convenções rigidamente delimitadas. Quanto a esse caráter essencialmente libertário da cultura carnavalesca, as ideias de Mikhail Bakhtin (1987) (aplicadas ao final da Idade Média e Renascimento) coincidem com a visão de Green e Swan, que analisaram a retomada da commedia no período de 1890 a 1930 pela arte culta. ${ }^{6}$

Falta ainda examinar um outro aspecto do interesse dos poetas e pintores pelos acrobatas e bailarinos, e ele tem a ver justamente com o salto, com a verticalização do corpo, com a capacidade de executar movimentos extraordinários, que remetem a um trânsito entre as alturas e o abismo, como no poema em questão:

Pierrot entra em salto súbito.

Upa! Que força o levanta?

E enquanto a turba se espanta,

\footnotetext{
${ }^{6}$ Sugerimos consultar, além de Bakhtin (1987), Green; Swan (1986). 
Ei-lo se roja em decúbito (BANDEIRA, 1994).

Por suas habilidades de acrobata, Pierrot consegue se alternar rapidamente entre dois espaços opostos: a altura do salto e o chão, pois rasteja, "se roja em decúbito". A ênfase nessas habilidades é tal que Bandeira encerra o poema com uma variante mais ousada desse gesto acrobático, que permite a Pierrot novo trânsito vertical entre os espaços, agora do chão ao céu:

\footnotetext{
Ele que estava de rastros,

Pula, e tão alto se eleva,

Como se fosse na treva

Romper a esfera dos astros!...
}

Nessas duas quadras, vemos que os movimentos são rápidos, verticais e nos dois sentidos: Pierrot salta para dentro do salão, vindo talvez das alturas (um ser que não é deste mundo?), "se roja em decúbito" para, ao final do poema, caído de rastros após o tapa de Colombina, saltar de novo, atingindo as alturas.

Na cena final de Petrushka (1911), o boneco-palhaço também é capaz de ocupar dois espaços opostos: seu corpo inerte está no chão, arrastado pelo showman, quando surge, nas alturas (no teto do teatro de marionetes, um teatro dentro do teatro), o seu espectro aterrorizante. $\mathrm{O}$ alto, entretanto, nem sempre é espaço de ventura: o Pierrot de Bandeira se eleva, mas na treva, como também era noite em São Petersburgo ao final da feira, na última cena do balé. No drama de Alexander Benois (Stravinski também participou da criação do enredo), a morte de Pierrot se dá à noite, e no roteiro a cena recebe uma marcação que reforça essa atmosfera noturna: "As Scene 1 but later in the Day. Night is an hour or so away" (ASHTON, 1985, p. 8).

Nas partes II e III de "A Canção das Lágrimas de Pierrot”, a loucura aparece muitas vezes e é ela que altera a tez e a mímica do palhaço trágico, falseia as suas canções e chega a dotá-lo de "tanta paixão diabólica" - um verdadeiro transe, que dá a Pierrot traços de Arlequim. Na antiga commedia, vale repetir, a lógica não é um valor, o caráter das personagens pode ser cambiante, e isso produz surpresa e comicidade. Aqui, entretanto, não se trata de uma volubilidade sem causa; "Aquele surto", ou seja, a loucura, é que modifica o caráter de Pierrot, acrescentando-lhe traços de violência: os dedos "que se lhe ensanguentam", as "cordas que se arrebentam". 
Ribeiro Couto faz uma outra leitura desse trecho do poema. Ele vê, no arroubo de Pierrot, "sarcasmo de anjo rebelde", "esgares cínicos" do "clown lastimoso" (COUTO, 1960, p. 71-72). Essa visão do crítico encontra bom abrigo nos versos: "Aquelas canções, aquele / Surto não é mais, ai dele! / Do que uma imensa ironia". A ironia seria intencional, a alegria fingida - é possível que sim. Por outro lado, também se pode pensar no contraste (irônico e louco) da existência simultânea, em Pierrot, dos arroubos de "tanta paixão diabólica" com a tristeza pela recusa da Colombina.

Na estrofe que servirá de introdução àquela que seria a canção "sincera" (parte IV), o poeta reforça a loucura como traço que define a canção da parte II. "Cantiga louca", aqui, pode indicar metonimicamente a loucura de Pierrot.

Fazendo à cantiga louca

Doloroso contracanto,

Por dentro borbulha o pranto

Como outra voz de outra boca (BANDEIRA, 1994).

A loucura reaparecerá algumas vezes no livro: no poema "A rosa”, Pierrot é "o pobre doido" e a boca da mulher amada é louca (versos 10 e 17, respectivamente). Em "A sereia de Lenau”, as sereias / mulheres (como Colombinas), "Andam em terra suscitando mágoas”, e é o amor de uma delas que leva o poeta de língua alemã, como Pierrot, "Ao oceano sem fundo da loucura". A loucura que aparece nos poemas de Carnaval é sombria, trágica, ligada a um isolamento do indivíduo - romântica, portanto. Nem sempre foi assim. Em suas origens, a loucura que aparecia no carnaval e na commedia era uma "alegre paródia do espírito oficial", uma "loucura festiva" (BAKHTIN, 1987, p. 35).

Como em "Pierrot Branco", a febre aparece em "A canção das lágrimas de Pierrot "E a sua fronte arde em febre, / Ai dele! e os cuidados matam-no" - , e nos dois casos alude simultaneamente à doença e ao desejo por Colombina: doença, morte e erotismo vêm atrelados, um traço recorrente da poesia de Manuel Bandeira.

A parte IV traz a canção que dá título ao poema. Um travessão inicial e aspas que são repetidas antes de cada verso reforçam uma mudança no caráter do discurso e da canção, que agora será uma confissão íntima, impregnada da sinceridade romântica. As três estrofes são um lamento escrito num tom único. Mas essa triste canção não consegue calar por completo a "cantiga louca", pois faz com ela "contracanto" - melodias simultâneas e dissonantes convivem nesse Pierrot. 
Existe uma oposição que permeia todo o poema. É a que se dá entre a atmosfera turbulenta e sensual do baile de carnaval (um plano terreno) e a graça ingênua, o amor puro, a "linda paixão" de Pierrot - um plano elevado, espiritual. Talvez não seja demais reforçar que essa oposição tem uma tradição romântica, não pertence ao carnaval em suas origens ou à antiga commedia, como é extensamente discutido por Bakhtin.

No carnaval medieval e renascentista, o rebaixamento ao plano terreno era visto como algo fundamental e regenerador. Alto e baixo tinham uma conotação apenas topográfica, e não de valor moral. As imagens do corpo apareciam impregnadas de um realismo grotesco em que o elemento material (portanto sensual) era identificado como positivo, universal.

$\mathrm{Na}$ idade moderna esse realismo grotesco se transforma, perde sua base material e se converte em um grotesco subjetivo, romântico: o corpo, a sensualidade e o erotismo passam a pertencer a uma "vida inferior". A aproximação do homem com o mundo deve se dar em bases abstratas e espirituais, não corporais (BAKHTIN, 1987, p. 16-17). Não é difícil perceber que o plano terreno, no poema de Bandeira, pertence a esse grotesco subjetivo, nada regenerador. Um grotesco ao qual se opõe a figura melancólica, espiritualizada, enfim, romântica de Pierrot.

Em “A canção das lágrimas de Pierrot" o poeta apresenta a personagem central de seu Carnaval. E essa apresentação de fato abrange muito da "figura sincrética" de Pierrot. Bandeira mantém e valoriza em seu palhaço trágico as alegres habilidades de bailarino e acrobata que a antiga commedia lhe dera. Como os artistas de seu tempo, entretanto, pinta uma figura que, justo por suas acrobacias, habita dois mundos simultaneamente - o do baixo corporal carregado de erotismo, um mundo torpe, inferior e ameaçador, e o da altura astral. E dá grande relevo ao seu canto triste, que os simbolistas haviam tornado tão melancólico.

\section{Os poemas com "sensibilidade Pierrot"}

Carnaval é um livro impregnado de uma "sensibilidade Pierrot" (Cf. GREEN; SWAN, p. 29$)^{7}$, mesmo quando a referência à personagem não é explícita. Muitos poemas do livro,

\footnotetext{
7 "Pierrot sensibility" é empregado muitas vezes ao longo do livro, sobretudo relacionado aos poetas cuja sensibilidade artística fez com que incorporassem, em momentos de sua obra, traços da personalidade de Pierrot como a obsessão amorosa, o fracasso na realização do desejo erótico e a melancolia. Em Retrato del artista como saltimbanqui, Jean Starobinski, mesmo sem utilizar o mesmo termo, traça um perfil de Pierrot que coincide em muitos pontos com a análise de Green e Swan. Por viés da profissão, Starobinski habilmente se aprofunda nas questões psicológicas que justificaram a identificação dos artistas do final do século XIX e início do século XX com o palhaço trágico.
} 
carnavalescos ou não, trazem traços do caráter de Pierrot, em uma atmosfera de melancolia e solidão.

Em "Sonho de uma terça-feira Gorda" o casal que contrasta com a multidão torpe, "ávida de promiscuidade", paira acima de todo o mundo terreno, luminosos (de um brilho lunar?) e com vestes negras, lembrando Pierrot. Como acontece em "A canção das lágrimas de Pierrot", esse poema traz dois planos distintos: um terreno, carregado de um erotismo degradado ("Iam em cima, empoleiradas, mulheres de má-vida, / De peitos enormes - Vênus para caixeiros.") e o outro diáfano, espiritualizado ("Íamos, por entre a turba, com solenidade.”). É como se Pierrot se desdobrasse nesse casal que, de tão afinado, parece um único ser. O amor está realizado, mas parece deslocado, dissonante em relação ao mundo que cerca os apaixonados.

Na última estrofe o poeta cria outros pontos de contraste sensíveis:

Nós caminhávamos de mãos dadas, com solenidade,

$\mathrm{O}$ ar lúgubre, negros, negros...

Mas dentro em nós era tudo claro e luminoso.

Nem a alegria estava ali, fora de nós.

A alegria estava em nós.

Era dentro de nós que estava a alegria,

- A profunda, a silenciosa alegria... (BANDEIRA, 1994).

A oposição entre lúgubre / alegre e negro / claro-luminoso se repete em outros versos do poema; ela assemelha-se à dualidade que Pierrot traz estampada em suas vestes (às vezes brancas, às vezes negras, às vezes uma metade branca e a outra negra) e se associa a seu caráter de palhaço trágico, já mencionado.

A alegria é reiterada ao longo de todo o poema: "sentimento de felicidade", "suave júbilo”, e no verso que aparece (com modificação) duas vezes: “- Dentro de nós, ao contrário, era tudo claro e luminoso." Mesmo com tantos reforços essa alegria é, entretanto, problemática, como já fora em A cinza das horas. Como compreender a alegria de um casal que tem o ar lúgubre e se veste de negro? O verso final (“- A profunda, a silenciosa alegria...") acentua o paradoxo, e ficamos suspensos não apenas pelas reticências, mas por alguma dúvida: existe alegria que seja tão profunda e silenciosa? Alegria de fundo místico, religioso, talvez: "um suave júbilo", "Como a espada de fogo que apunhalava as santas extáticas". Mesmo essa alegria, pela própria imagem da espada de fogo, é atormentada.

Outros poemas de Carnaval, como "A sereia de Lenau" e "Toante", nos remetem à sina de Pierrot. E a amante volúvel de "Do que dissestes..." tem algo de Colombina: 
Hoje, contudo, nem me olhais...

Pobre de mim! Por que seria?

Acaso arrependida estais

Do que dissestes?

(BANDEIRA, 1994)

Em "A fina, a doce ferida...", a expressão "a dor do meu gozo" condensa prazer e dor com tal força que pode nos remeter à obsessão amorosa. Um gozo que deixa, além de dor, culpa, "ardor pecaminoso".

Então, a despeito da escolha do carnaval como tema (e do grito de abertura que antecipa a fase combativa do modernismo: "Quero beber! cantar asneiras"), a presença marcante de um Pierrot lunar dá a Carnaval uma atmosfera neo-simbolista, em que a melancolia e a solidão aparecem tratadas não em um tom solene e diretamente confessional, mas mediadas pela commedia dell'arte, literalmente mascaradas.

Carnaval, como o próprio poeta afirmou, é um livro heterogêneo. Feito de muitos contrastes, e de um lirismo descontínuo, traz alguns poemas que antecipam uma nova dicção poética, como "Os sapos”, "Debussy” e "Alumbramento". Mas é a figura débil de um Pierrot inspirado na tradição simbolista que, como o espectro de Petrushka, ronda o livro.

\section{Referências bibliográficas:}

ASHTON, Geoffrey. Stories of the ballets; Petrushka. Great Britain: Aurum Press, 1985.

BAKHTIN, Mikhail. A cultura popular na Idade Média e no Renascimento: o contexto de François Rabelais. São Paulo: Hucitec, 1987.

BANDEIRA, Manuel. Itinerário de Pasárgada. Rio de Janeiro: Nova Fronteira, 1984.

. A cinza das horas; Carnaval; $O$ ritmo dissoluto. Edições críticas de Júlio Castañon Guimarães e Rachel T. Valença. Rio de Janeiro: Nova Fronteira, 1994.

BAUDELAIRE, Charles. Pequenos poemas em prosa. Rio de Janeiro: Nova Fronteira, 1976.

COUTO, Ribeiro. Dois retratos de Manuel Bandeira. Rio de Janeiro: Livraria São José, 1960.

ENZENSBERGER, Hans Magnus. Linguagem universal da poesia moderna (1962). In: Com raiva e paciência: ensaios sobre literatura, política e colonialismo. Rio de Janeiro: Paz e Terra, 1985.

GREEN, Martin; SWAN, John. The triumph of Pierrot: the commedia dell'arte and the modern imagination. Pennsylvania: Penn State Press, 1986. 
REZENDE, Luiz Carlos de Britto. De que riu o Pierrô? In: Jules Laforgue. Últimos poemas do Pierrô Lunar. Rio de Janeiro: Sette Letras, 1997.

STAROBINSKI, Jean. Retrato del artista como saltimbanqui. Madrid: Abada Editores, 2007.

\title{
Manuel Bandeira's Carnival and the commedia dell'arte
}

\begin{abstract}
Manuel Bandeira published Carnaval (1919) in a specific artistic context, when composers, painters, novelists and poets of the late nineteenth century and early years of the twentieth century (symbolists and early modernists) were inspired by commedia dell'arte, a popular theater expression based on masks, mime and improvisation. The closest relationship between the poets and commedia was through a Pierrot, a lunar character that descended from A.Watteau's paintings and from the recreated character from the funambules theater by J-G. Deburau. The archetypal figure of the Pierrot, which is identified with what is sad and lonely in the life and work of the poet, structures most of the work in Carnaval, contributing to the dominance of neo-symbolist atmosphere where melancholy and "bad fate" that appears being treated not in a solemn or directly confessional tone, but mediated by the commedia dell'arte.
\end{abstract}

Key words: Brazilian poetry. Manuel Bandeira. Carnival. Commedia dell'arte.

Recebido em: 01 de junho de 2013.

Aprovado em: 01 de julho de 2013. 